\title{
THE MAINSPRING AND RECRUITING MECHANISM OF THE EGYPTIAN MUSLIM BROTHERHOOD UNDER AUTHORITARIAN REGIMES
}

\section{Mohamed Chami MKOUBOI}

Graduate School of Social and Cultural Studies, Kyushu University, Fukuoka, Japan

Chami63@hotmail.com

\begin{abstract}
To understand the Egyptian Muslim Brotherhood's mobilization, the readers should consider several factors. The factors are divided into two categories. The first category is based on macro analysis, while the second is based on microanalysis base. The Macro analysis is defined by the historical explanations explaining the fundamental reasons behind the sympathetic nature from the Egyptian society towards the religion of Islam, and intending to be politically independent from the West. The microanalysis in this paper presents the different steges pursued by the Organization to invite the Egyptian individuals to join the Organization.
\end{abstract}

\section{Indexing terms/Keywords}

Egyptian Muslim Brotherhood; Macroanalysis; Microanalysis; Recruitment mechanism.

\section{Academic Discipline And Sub-Disciplines}

The Department of Social and Cultural Studies, Political Science.

\section{SUBJECT CLASSIFICATION}

Political science, Political Islam, Egyptian Politics.

\section{TYPE (METHOD/APPROACH)}

Historical Inquiry;; Literary Analysis; Survey/Interview/observation.

\section{Council for Innovative Research}

Peer Review Research Publishing System

Journal: Journal of Social Sciences Research

Vol. 6, No. 2

Jssreditor.cir@gmail.com

www.jssronline.com 


\section{INTRODUCTION}

This paper is a report highlighting the driving force of the mobilization and the recruiting mechanism of the Egyptian Muslim Brotherhood (EMB) mainly from 1930s until 2014. As the recruitment of the Brotherhood is still mysterious for many researchers and observers (Al-Anani 2007, 110), the study was based primarily upon examining selective academic works made by a number of scholars who are considered as the most devoted ones in the field of the Muslim Brotherhood studies. Both Richard P. Mitchell (1969) and Khalil al-Anani (2007) are among many others who made much effort to meet as many active members of the society as possible for the purpose of interviewing, surveying and questioning how they joined the Organization. In addition, the work of Ziad Munsun (2001) was significant for this particular paper. The latter stated that "at the height of its popularity, the Brotherhood had half a million active members in an Egyptian population of less than twenty million, proportionally more than twice as large as the American Association of Retired Persons (AARP), one of the most powerful lobbying groups in the United States in the 1970s" (Munson 2001, 1).

To understand the purpose of this study, the author primarily covered the background of the study and the historical background that facilitated the Brotherhood to recruit members and sympathizers. The historical background section is divided into the following sections: (1) the rise and decline of Islam's authority, (2) Egypt and its connection to Islam, (3) the height and decline of the Ottoman Empire,(4) Egyptians vis-à-vis the Western Imperialism, (5) resurgence of Political Islam in the late $19^{\text {th }}$ century, (6) the defeat of the Arabs by the Israeli army, (7) the social welfare to the Egyptian citizens by the Brotherhood, (8) the Egyptian economic crisis from mainly 2004 to 2011 under Hosni Mubarak regime and finally (9) the political opportunity of the Brotherhood due to the Arab Uprising's effects started on January $25^{\text {th }} 2011$. The second main part of the study presented the different stages and steps of the recruitment and the membership.

\section{BACKGROUND OF THE STUDY}

The Egyptian Muslim Brotherhood's recruiting method is still mysterious for many researchers and observers, especially after its success to win the presidential election on June 24, 2012. Accordingly, researchers found out the different backgrounds on which the recruiting mechanism could take place from 1930s to 2012. Nevertheless, no clear criteria or norms yet explained the different steps the targeted citizens went through. Usually, researchers such as Richard P. Mitchell (1969) presented and explained the different levels within the Organization itself, not from none membership status to an active membership. As example, Richard P. Mitchell mentioned that:

"at the third General Conference in 1935, Al-Banna defined three degrees of membership: (a) 'assistant' (musa 'id)); (b) 'related' (muntasib) and (c) 'active' (ami). In the beginning, any Muslim who declared his intention to join could just signed a membership card, agreed to pay dues, and ultimately he could be accepted as 'assistant' member. He became a 'related' member when he proved his mastery of the principles of the movement, attended regular meetings, and committed himself to 'obedience'. He attained the degree of 'active' member with his total involvement with the movement, physical training, achievement in Qur'anic learning, fulfillment of the Islamic obligations such as pilgrimages, fasting and contributions to the zakat treasury. A fourth degree of membership, named 'struggler' (mujahid) was the final stage, opened to only a select a handful of the most dedicated" (Mitchell 1969, 183).

This forth stage is not common among researchers because it was demolished through the different reforms pursued by the Organization along its history, due to the accusation of violence by the successful governments.

The originality of this paper is the combination of the macro and micro- analyses as a dual explanation behind the recruiting phenomenon of the Brotherhood. In terms of strategy, the social welfare activities to the Egyptian lower and the middle classes by the Organization is often cited as the driving force of the huge recruitment among Egyptians. However, this explanation ignores members who are belonging to high-class, with neither economic nor financial interests from the Brotherhood. In fact, the members of the Organization are a mixture of all social and economic levels including members from prestigious families. Some other scholars only emphasized on the suppressive attitude of the successive authoritarian regimes as the driving force of the Organization's victimization that attracted many Egyptians to support the Organization. The brutality of the successive governments is the principal argument of 'the resurgence of Political Islam theories'. These limited explanations inspired the author to broaden the reason behind the recruiting dynamism of the Brotherhood started from the macro analytical explanations of the Recruiting phenomenon to end up by the micro analytical techniques.

\section{MACRO-ANALYSIS OF THE BROTHERHOOD'S RECRUITING PHENOMENON}

The Macro-analysis means the historical explanations highlighting the Egyptian sociological and political implications in favor of the Egyptian Muslim Brotherhood's recruitment before and after its inception "on March 1928" (Mitchell 1969, 8). Reading from the literature explaining the EMB's social and political aspects, there might be other factors explaining the recruiting phenomena such as the philological and ideological approaches used by the Brotherhood's leaders. However, the letter actors measured what the ordinary Egyptian society relies on the sociological and political inspirations. Overall, the author only selected few of the influential explanations behind the accessibility to EMB's huge mobilization started from the belief that the EMB is the solution of the 'Rise and Decline of the Islam's Authority' in the Arab World. 


\subsection{The Rise and Decline of Islam' Authority}

Like other contemporary Muslim reformers in the Muslim World, the Egyptian Muslim Brotherhood leadership acknowledged the view that Islam's decline happened after the end of the period of the first four caliphs after the Prophet. The state, which was governed by the established caliphs (al-khilafat al-rashida), was strictly representative of Islam as a faith and a system at the same time (Mitchell 1969, 210). The people selected the leader based on specific qualifications such as his strict practice of the Islamic texts and his trustfulness. The four first caliphs who succeeded the Prophet were the source of authority after him one after another. They were pious, learned in the spirit and the law of Islam. Mitchell stated, "the treasury was at the deal of the people, for the people had a right to demand that the ruler and state be accountable for the fulfillment of their needs. In addition, in the state, there was unity in the brotherhood of religion and equality in rights and duties" (Mitchell 1969, 2010). This remembrance remained in the memory of Islamic movements in general and in the agenda of the Brotherhood in particular in the late of the 19 Century. As an obstacle of achieving a similar governance system to the four caliphs, authoritarian leadership could control power for centuries in the Arab World.

Consequently, for Islam, by mischance, political control passed into the hands of the house of Mu'awiya. Accordingly, Mitchell stated, the Umayyad period of Islamic history saw the leadership become a kingship belonging to one family with arbitrary power, indifferent to the popular source of authority. The rulers with no sense of true Islam continued governing based on the pride of his tribe. The treasury became the private purse of the ruler to the detriment of the needs of the people and the interests of the nation; the tribalism of the ignorant Arabs reawakened and factionalism became a tool of the ruler to maintain power; morality and obedience to God despised and neglected; and individual rights and freedom sacrificed. Throughout the Umayyad period, only the rule of the $8^{\text {th }}$ caliph, 'Umar Abdel Aziz', known as Omar II (717-720) evidenced the inner strength of Islam (Mitchell 1969, 210). After Omar II, the record of his following successors was not good until another phase of leadership called Abbassid.

After the Umayyad, the Abbasid successors of Damascene (Syria) rulers provided the unhappy climax to the disintegration of the Islamic community.

"Under them, inherited ruler-ship evolved into a divine right of the sultanate. Praise, servile flattery, and tribute of the ruler, right or wrong, became the rule. The rulers wallowed in luxury, pomp, wealth, silks, and, some say, drink; they lived off the public purse, their private lives related in no way to their mission as leaders of the message of Islam. They played on Persian and then Turkish tendencies in the milieu, thereby aggravating the dissensions in the Arab community begun by their predecessors" (Mitchell 1969, 2010).

Muslims in the Middle East and North African regions learn the history of both Umayyad and Abbassid's era in a debatable approach. However, there is a consensus among at least all Muslims sunnit that the successful periods of the Islamic authority were the period of the prophet, the periods of the four caliphs after the Prophet and during the period of Omar II only. The Brotherhood attempted to inspire Muslims not only in Egypt but in the entire World that the Organization would bring back the pride of Islam at least as it was during the period of Omar II. Therefore, the language used in the seminars, mosques and other occasions is about convincing the audience that they would be the alternative in favor of the Islamic prosperity as many Muslims hope in the $20^{\text {th }}$ and $21^{\text {st }}$ Centuries.

Mitchell also precisely highlighted that

"the height of Islamic world power was only a façade, which concealed bitter political disputes and factionalism. Religious and school (legal) disputes led to an Islam of words and phrases rather than faith and action; fanaticism replaced discussion and debate; stagnation overtook the religious community; and the practical sciences were neglected for theoretical philosophies. Moreover, the power focus shifted and leadership was transferred to non-Arabs-Persians, Daylamites, Mamlukes, and Turks, none of whom ever tasted the real Islam because they could not perceive presumably because of the language its true meanings. In this setting, the first catastrophes struck and then multiplied the Crusaders, the Tatars, the Carmathians, and the push of Europe against Muslims in Spain, and on the peripheries of the Islamic world as Europe opened its era of discovery" (Mitchell 1969, 2010-210). This historical legacy sharped the ideology of the Brotherhood to think about recruiting more members in Egypt where Islam is very influential.

\subsection{Egypt and its connection to Islam}

The center of the oldest civilizations of humankind, Egypt was the suitable and historically right place for Islam to base itself in 642 A.D. Islam has been the dominant religion of Egyptians until today. Accordingly, Muslims become dominant that we can see it clearly in all aspects of life among Egyptians. Muslims constitute about $90 \%$ of Egyptians with the other $10 \%$ who are mainly Christians. When Islam entered Egypt after the defeat of the Romans on the hands of the Arabs, most Egyptians converted to the new religion while some Egyptians remained Christians. The conversion came as a normal result of the Arabs' virtues seen by Egyptians as the touch of Islam on them, in fact conversion happened gradually throughout years of Islamic rule. When Amr Ibn El Aas, the Arabian army leader, conquered the Romans, he assured people that their lives and belongings will not be touched; they will be safe in their homes. The Egyptian patriarch was hiding in fear of the Roman suppression because of his beliefs, since the Islamic conquer; he got out of his hiding to practice his authority fearlessly (Islamic Egypt 2011, 1). 
Actually, Egypt welcomed Arabs as religion callers, peace and good patrons. Amr Ibn El-A'as and his soldiers entered Egypt and struggled against the Romans, who occupied Egypt and Syria and caused their people all sorts of misfortune. That is why, so many of the Egyptians back then, joined the Islamic troops against the Romans, since they found in Islam, the freedom and dignity that they have missed during the Bezantian ages that someone of them said: the history did not realize more merciful invaders than the Arabs in Egypt. The commitment of the Egyptians in early ages to Islam, and the engagement of their history with the Islamic ideology have strengthened the most powerful tie, and strongest relationship between them and their faith. Islamic faith helped them a lot in their struggle against all the hard challenges and the invaders campaign from Tatar and crusades and the escape of the invaders throughout the history. In addition, this helped them to maintain their Islamic ideology before and after the demolition of the Othman Empire (Islamic Egypt 2011, 1). After the end of the Othman Empire, Egyptian Muslims like other nations in the Muslim World keep the hope of bringing back the pride of Islam maintained by the Othman Empire for six Centuries, accordingly, the Brotherhood was the first Islamic movement with the vision of establishing an International Islamic block similar to the Othman Empire.

\section{3 The decline and height of the Ottoman Empire}

The decline of the Muslim authority took place after a long period of at least six Centuries of dominance under the Othman Empire. The Turkish or the Ottoman Empire was considered as one of the 10 great lasting Empires in the human history. In the Muslim World, it is common to listen to stories related to the great Ottoman Empire. Based on this pride, Muslims in general learnt that during that period the Islamic states were ruled under a vast dynamic geography (Sicker 2000, 261). The capital city of the Empire presently named 'Istanbul' was considered as a "city of interactions between the Eastern and Western worlds" (Sicker 2000, 261).

"During the 16th and 17th Centuries, in particular at the height of its power under the reign of Suleiman the Magnificent, the Empire became the most powerful state in the world, a multinational, multilingual Empire that stretched from the Southern borders of the Holy Roman Empire (until the outskirts of Vienna), Royal Hungary (modern Slovakia) and the Polish-Lithuanian Commonwealth in the North to Yemen and Eritrea in the South; from Algeria in the west to Azerbaijan in the East; controlling much of Southeast Europe, Western Asia, and North Africa. The Empire contained 29 provinces and numerous vassal states, some of which were later absorbed into the Empire, while others were granted various types of autonomy during the course of centuries"(Sicker 2000, 261).

The western scholar Samuel Huntington published in 1996 his famous article 'clash of civilization and the Remaking of the World Order'. Reading from Huntington, the author assumes that the Brotherhood did efforts to recruit as many members as possible in the 1930s and 1940s as a means of trying to reach social and political standards allowing the Organization to initiate a new Islamic International Oder as the Othman Empire was. Accordingly, Huntington stated, "the burden outlines of present conflict will not be based on territories or states but' civilizations" (Huntington 1996). In his turn, the founder of the Brotherhood, Al-Banna, said that Turkey, under Mustafa Kemal, wrongly demolished the caliphate and he separated the state from the religion (Albaz 2010, 80). As result as the latter vision, the Brotherhood found itself in political conflict with the British and consequently the Brotherhood played a great role with other nationalist parties to evacuate the British officials from Egypt. Accordingly, Huntington pointed out the 'Judeo-Christian' civilizations vs. the Islamic Civilizations. Similarly, Daniel Pipes is critical and questioning the real agenda of 'the Brotherhood in the Middle East as well as in the West. Pipes' statement on his book 'Militant Islam Reaches America' is that the adherents of Islam like the Brotherhood find their faith immensely appealing for Islam, has an inner strength that is quite extraordinary (Pipes 2002, 3). Pipes' entire book demonstrates how confident Political Islam actors such as the Brotherhood think of considering US as a target like other European countries. Based on the Brotherhood's ideology, Zionism aided by imperialism in the heart of the Arab and Muslim World continues with impunity to suppress the Palestinians.

\section{4 Western Imperialism}

Following the decline of the Ottoman Empire, Sami Cherkaoui states that:

"The strength of the Ottoman Empire reached its maximum weakness in the beginning of the 20th Century, and encouraged European States to conspire for defeating it politically and militarily; certain areas of the Empire such as Egypt and Algeria became independent in all but name, and later came under the influence of Britain and France" (Cherkaoui 2011, 8).

The above narrative indicates the end of the Ottoman Empire and the interference of the Western countries led by the British and the French imperialists in the Middle East and the North African regions. More importantly, it is common knowledge among Middle Eastern historians that the United States never declared a war against an Islamic country in the 19th Century. However, as US became the principal actor of today's Western World, many Muslim communities including the Brotherhood believe that the Christian World in general and the US in particular share the same agenda against any attempt for Muslims to be self-dependent; especially after the first gulf war against Saddam's regime in 1990, followed by the war in Afghanistan after the September $11^{\text {th }}$ incidence in 2001. Similarly, the Western public opinion looks at the Brotherhood as a danger, especially after September 11th tragedy in which among the participants were Egyptians. Furthermore, the EMB is considered a new version of the expansionism ambition of the Ottoman Empire.

During the period of Al-Banna, the British and the French had the similar image with the U.S today in front of the Egyptian society. Accordingly, Albaz noticed in Al-Banna's memory that Muslim citizens in the region look at the French and the British colonizers in the beginning of the 20th Century in suspicious etiquettes, especially in Egypt where an uprising of bad feelings among the citizens against particularly the British imperialism was remarkable (Albaz 2011,51). Forthwith, Hassan Al-Banna, "MB's founder involved in the labor right struggles against the policy of the French and British 
monopolistic companies" (Albaz 2011, 50-51); the latter author mentioned that when Al-Banna was working under the British rule, before engaging his enduring job as a school teacher later on in Ismailia embraced an anti-imperialism ideology. According to Mitchell, six friends working in Suez Canal under the British rule suggested to Al-Banna to establish an organization for the purpose of defending labor right and promoting the Islamic ethics (Mitchell 1969, 8). Later, this Organization became the Muslim Brotherhood.

Hassan Al-Banna's group was not happy of the promotion of the Western values within the Egyptian society. In this regard, Pargeter Alison stated an interesting paragraph suggesting that MB's founder 'Hassan Al-Banna' was concerned about the western influence over the Egyptian society as it has been stated by Albaz Although Hassan Al-Banna did not reject the West in itself, he certainly had major concerns about the impact of Western culture on his own society, asserting: Western civilization has invaded us by force and with aggression on the level of science and money, of politics and luxury, of pleasures and negligence, and of various aspects of life that are comfortable, exciting and seductive (Mitchell 1969, 330). One of the most important incidences in favor of the Brotherhood's recruitment is Egypt's struggle for a complete independence in 1956 (Beinin and Lockman 1998, 12-13). Khalid Munson stated, ideologically, continued British occupation of Egypt after the First World War created a highly visible target on which to focus the brewing discontents of the population. When the organization became politicized in the late 1930s, most of the invective in its newsletters and speeches of its leaders was directed against the British (Wendell 1978; Kepel 1993), and it was ultimately the British, who first tried to suppress the Organization (Munsun 2001, 495).

In the case of America, the doubt over the Islamic movements in general played a negative role during the Washington's War against terrorism. The Brotherhood's record is not under a black list by the American Federal Bureau of Investigation (FBI). However, as some Egyptians involved in the tragedy of the coordinated terrorist attacks launched by al-Qaeda upon the United States in New York City and the Washington, D.C., on Tuesday, September 11, 2001, the Americans were unwilling to ensure cooperation with any Islamist movements in general. However, it seems that the Muslim Brotherhood was successful to deny and condemn the September 11th 2001 terrorist incidence. Nevertheless, the Mubarak regime was successfully convincing the US to not trust the organization as it has an agenda to pursue terrorism and antiAmerican Middle East policy whenever they get chance in the future. Accordingly, Pargeter stated, "the Egyptian government presents the Egyptian Ikhwan (Brothers) as the political face of a terrorist organization"(Pargeter 2010, 178). $\mathrm{He}$ added "there are also repeated assaults on and warnings about the Brotherhood in the state-controlled media" (Pargeter 2010, 178). Consequently, the Brotherhood got the opportunity to recruit more members during the period of the war against terrorism led by Washington. This Washington's intervention in Middle East internal affairs has grown antiAmericans among Arabs and Muslims. Thus, in Egypt, the Brotherhood could win the heart of many Egyptians.

Another argument to explain the sympathy among Egyptians towards the Brotherhood was the Brotherhood's relationship with Hamas. The latter Organization is considered as a terrorist organization. Pargeter stated a quotation from the former President Mubarak saying that:

"the victory of Hamas and the Brotherhood at the ballot box does not mean that they are politicians and that they are capable of running the state. All that Hamas is capable of doing is to be crack troops of suicide. Unfortunately, they are not committing suicide alone. They are forcing people to commit suicide, and I fear that this is the same tactics and path that the Brotherhood in Egypt is taking" (Pargeter 2010, 178).

This doubtful statement is similar to what the President Abdel Fattah el-Sisi emphasized on nowadays against the Brotherhood. The current Egyptian authority engaged similar accusations after the removal of Mohamed Morsi from power by the Egyptian army on 3 July 2013. For the Brotherhood, the coup was backed by the United States as it has been stated by Evan Eland "American diplomats secretly pressured the Brotherhood to resign itself to Morsi's ouster by the Egyptian military" (Eland 2013). After the 2013's coup led by General Sisi, observers cannot predict yet the future of the Brotherhood. However, based on its hidden activities' experience, the Brotherhood might continue working underground, especially as the Egyptian government in cooperation with the Israeli and the U.S governments work harder to weaken the Organization.

\section{5 The after defeat of the Arabs by the Israeli army backed by the U.S}

The defeat of the Pan-Arabism by the Israeli Army in 1948 and in 1967 gave the Brotherhood a recruiting opportunity to appeal as the alternative political force in the region in general and in Egypt in particular, instead of the weak nationalist Pan-Arabism. During these painful periods, the popularity of the Brotherhood in Egypt reached a tremendous influence especially in the 1960s after the defeat of the Arabs. Edwards Said stated that Political Islam mainly represented by the Brotherhood "is widely recognized in 1967, starting from the crushing military defeats of Arabic countries at the hands of Israeli forces" (Edwards 2000, 123). Scholars in Political Islam mentioned the Brotherhood's participation in the war under the Egyptian military forces against the Israeli army. Since then, the Islamic revival became the main opponent instrument against the socialist and nationalist parties on the domestic levels. In addition, the Islamism represents itself as the best option among other political actors in the Middle East and North African regions to challenge the Israeli economic and military capabilities. Both the struggle for a complete independence from the West led by the United States, and the challenge against Israel represent the resurgence of Political Islam in general in the Arab World, thus one of the sources of the Brotherhood's mobilization.

\section{6 Resurgence of Political Islam}

The Egyptian Muslim Brotherhood as the main actor of 'Political Islam' is considered as a new wave of politics flourishing mainly in the Middle East in the 1930s. The purpose of rebuilding and reforming a political force since the late of the 19 
century was the mainstream ideology under several Muslim scholars. "The prominent Muslim reformist scholars of the contemporary 'Political Islam' are Jamal ad-Din al-Afghani (1838-1897), Muhammad Abduh (1849-1905) and Muhammad Rashid Reda" (1865-1935) (Ramadan 2011, 159). Al-Afghani and Abduh were known as the reformists of the literal interpretation of Islam. Many Scholars in Political Islam beside Tareq Ramadan often mentioned that the founder of the Brotherhood Hassan al-Banna has been inspired and motivated by those three Islamic reformists. As a Muslim country, Egypt under the influence of reading the Islamic texts in a comprehensive method under mainly 'Al-Azhar University', rather than literal reading, the ideology of the Brotherhood was rapidly accepted by the Egyptian society emotionally and logically. Khalid al-Anani highlighted an interesting phenomenon explaining the recruiting mechanism under a religious base. Based on his questionnaire and survey, Al-Anani mentioned that $75 \%$ among the people he met said that they joined the Organization only because of its religious foundation. This is not unambiguous for an Organization intended to establish an integrated Islamic project in a country like Egypt (Al-Anani 2007, 75).

Al- Anani continued his argument suggesting that the mobilization of the Brotherhood is based on two fundamental factors: 1) a memory of sociological religious aspect which has been developed by the French sociologist Maurice Halbwachs (1877-1945) in his book 'les cadres sociaux de la memoire' (1925). Halbwachs' principal explanation is based on a classical argument suggesting the need of the societies to revive a system of rituals and beliefs from the past. This vision is still influential within the ideology of any given society and in the Islamic World in particular. 2) The 'sociology of hope' in which the principal argument comes from 'Sufism'. The first scholar who studied this phenomenon was the French thinker Henri Desroche (1914- 1994). Desroche attempted to explain how far the religious communities are keen to overtake all problems and tragedies generated by the present-day to a brilliant future. This empirical argument emerged in the 16 and 17 Centuries in Europe in a social movement called 'the protestant movement' (Al-Anani 2007, 75-76).

In the case of the EMB, the activists of the Organization conveyed a message to their Egyptians counterparts through their speeches that the importance of collective activities as the only way to build a future full of prosperities and selfdependence. This message reaches many Egyptians who have already received the Islamic ideology from mosques and other Islamic centers. To test this argument, Al-Anani interviewed Brotherhood's members based on the following question: why did you embrace the Muslim Brotherhood? Even though, answers from one member to another were different, from university students, rural and villages to urban and big cities, all of them had a common ground: a historical religious memory is the driven force for them to spend time, money and children for the sake of the Brotherhood' success. These efforts are made for a hope that one day Egypt will succeed to stand with their own feet as it did in the past (AlAnani 2007, 77).

\section{7 The social service activities rendered by the Brotherhood}

This section presents and examines the economic and the social assistances of the Muslim Brotherhood toward the Egyptian society. The successful mobilization of the Muslim Brotherhood was possible because of its economic and social activities through the Muslim Brotherhood's organizational structure to assist everyday lives of Egyptians. In the beginning, the Muslim Brotherhood was an explicitly apolitical religious reform and mutual aid society during the organization's early years. It devoted its energy to membership recruitment, private discussions of religion and moral reform, and building a social service organization. The extensive supports MB gained among the Egyptian society was its welfare system and health services for the middle and lower classes of the Egyptian society. Such actions are also generated from the Muslim Brotherhood's ideology, stressing on social responsibility and concern for the welfare of fellow Muslims. It was in under table activities under Nasser's regime and experienced considerable reappearance under Sadat and Mubarak's regimes.

As with its preaching and the education services, the welfare activity also rotates around the mosques.

"MB offers the services through regional directions engaged by its administrative network. Islamic institutions' links and NGOs across Egypt are a major platform for this goal. MB affords health services, subsidized clothing and food for students; social activities; separate transportation for women. In the poor districts, the organization works supplying services, conducts wedding ceremonies, and distributes food, clothing, and money in exchange for adherence to Islamic law" (The Meir A, Intelligence 2011).

The facilities delivered by MB are cheaper than private alternatives, and are more competent than the usually low-quality services provided by the government. According to the same source, this is an outcome of the high rate of volunteers among the MB's members and the constant funding it obtains from contributions. The privatization plan and the state's removal from its major role have strengthened the position of Islamic networks as sources of social services. The Egyptian citizens apparently assist the Brotherhood' social services and welfare activities in its daily life especially during the economic crisis started mainly from 2004.

\section{8 The Economic crisis from 2004 to 2011}

The Egyptian economic situation has never reached a satisfactory standard for about 80 years. The authoritarian regimes used to offer many privileges to the bureaucrats and other government officials. However, the Egyptian society suffered a lot in the period of 2004 to 2011. During this period, the ruling elite headed by Gamal Mubarak monopolized the country's assets. The country was about to experience a complete collapse caused by corruption, the new capitalism and a low rate of economic performance. Unfortunately, this situation was the result of the privatization policy and the shift towards a market economy (Al-Anani 2007, 53). Furthermore, corruption began to spread within the Egyptian society, especially with the crime of bribery that became exacerbated in various governmental and private sectors. Over the past decade, corruption spread throughout the financial and banking sectors too, because of the corruption in granting loans and the negative impact of political and financial interventions to break rules and laws. 
The Egyptian Central Bank cited in its statistical Bulletin for the month of June 2005, doubtful debt was about $14.4 \%$ of the actual loans provided by the Egyptian banks in March 2005 (Al-Anani 2007, 53). This means that the total value of the doubtful debts reaches 49 billion Egyptian pounds. The uncollected interest is much bigger than the previous amount. Indeed, the loans of the private sector rose from 29 billion Egyptian pounds in 1992. This latter figure happened when the program of shifting towards free market economy demanded about 204 billion Egyptian pounds in 2004 according to the Egyptian Central Bank (Al-Anani 2007, 53). These data can help to highlight the financial and economic mismanagement that contributed in worsening the Egyptian society's financial conditions. Thus, the Brotherhood with its social service activities got the opportunities to present itself as the alternative political platform to the Mubarak's regime, and consequently, the organization recruited members and sympathizers from the Egyptian society who later on, revolted against the Egyptian authority under the Arab Uprising.

\section{9 Arab Uprising Political Opportunity}

Arab Spring or Arab Uprising depends on what the readers would like to call the huge mobilization against ruling elites in the Middle East and the North African regions. The Uprising is a term related to a wave of mass protests and demonstrations, which could be observed from December 2010 in Tunisia. In numerous countries, the turmoil transformed from street riots into arms battles of the protesters with the forces of the defending regimes (Maszner 2011, 5). The situation in the region where riots took place is still instable (Maszner 2011, 5). The increasingly intense protests were both political and economic in nature. The social discontent was caused by a high level of unemployment, unsatisfactory living conditions, limited civil rights and corruption observed in political circles. The members of the conflicts were kindled by the representatives of political and religious movements, which considered this a chance to implement their own programs. One phenomenon of the Arab Uprising was the social involvement of the new media in the course of events and the use of technologies such as the internet as a carrier of information supporting the activity of the rebels. Rewizorski suggested that the Arab Uprising is really about jobs, bread, and housing rather than democracy, which is second in line (Rewizorski 2011, 10).

These protests found the Brotherhood on the way for more than 80 years. Subsequently, the Organization was in a good shape to get as much advantage as possible in terms of mobilization. Its active members worked days and nights to gain more sympathizers and supporters to participate in the struggle to remove Mubarak from power. In Egypt, the Uprising was successful to remove Mubarak's regime on January 25th 2011. These activities for the Brotherhood were not difficult to be well performed and coordinated due to the Organization's experience in the field of social services and welfare activities since its inception in 1928. The Brotherhood has been described by the international media as the well-organized political institution within the Egyptian political sphere and dynamic in terms of recruitment.

\section{MICROANALYSIS OF THE EGYPTIAN MUSLIM BROTHERHOOD'S RECRUITING MACHANISM}

In an effort to explain the recruiting strategies under micro analysis approach, Al-Anani Khalil suggested that "in the purpose of reforming the organizational structure, there is an agreement presenting that the membership's degrees are: a) 'attached' (al-Muhib); b) 'regular' (al-Muntazim); c) 'active' (al-Amil). Al-Anani explained that this new category is the existing category except in few branches where the circumstances imposed a different system. This categorization does not respond the fundamental question: how the Brotherhood's member invites or attracts the ordinary citizen to the Organization. In responding this question, the author would examine and analyze Al-Anani' suggestion. The latter stated that we could understand the different steps by understanding the actual moving map on which the Organization follows (Al-Anani 2007, 111):

\subsection{The base of the general working environment}

This is the largest environment in which the Brotherhood targets a huge society though its social welfare activities, Islamic seminars, worshipping activities, educational institutions and sport activities. In such environment, it is not necessary to identify the citizen wanted or targeted by the Brotherhood`s activists. The mechanism is similar to a fisherman who throws his nets to catch whatever possible from the sea.

\section{2 General encircled networks}

This is a special case intending to target the citizen who seems to engage a better friendship or relationship with the Organization, whether family members or friends.

\section{3 The private call.}

The initiative contact is to target a particular individual with a particular character suitable for the Organization. In this case, it is easy to invite the individual.

\section{4 The attached membership}

This level is the first and actual step to join the group. The member in this stage is already ideologically persuaded by the Organization's agenda. However, there is the need to get the organizational, ideological and spiritual educations. Thus, he can register his name in any branch or committee.

\section{5 The regular membership}


This stage is a mixture of the 'related' and the 'regular' membership in one category which is 'regular'. Some of the units still keep the old system which separate the 'related' from 'regular'. The Brother now starts getting intensive learning program for the purpose of raising his organizational awareness, such as the commitment of the Brotherhood's ethics, the commitment of regular worship, the commitment of good manner and behavior and the organizational commitment. This member has the right to vote only on the branch level.

\section{6 The active Brotherhood}

This is the last stage in terms of membership, but the member should spend at least three years in the Organization. In addition, he should not have any bad record. This member has the right to be candidate in any of the Organization's internal elections. Moreover, he should pay the membership monthly fees based on his economic and financial levels.

\section{CONCLUSION}

To understand the Egyptian Muslim Brotherhood's mobilization, the readers should consider several factors. Those factors are divided into two categories. The first category is based on macro analysis while the second is based on microanalysis. The Macro analysis is defined by the historical explanations indicating the fundamental reasons behind the sympathetic nature from the Egyptian society towards the religion of Islam and intending to be politically independent from the West. The microanalysis in this paper presents the different mechanisms pursued by the inner circle to invite the Egyptian individuals to join the Organization.

\section{ACKNOWLEDGMENTS}

I express my warm thanks to my family for supporting me to edit this paper and guide me to write it tirelessly. I would also like to thank my supervisors MATSUI Yasuhiro, YAMAO Dai, MASUO Chisako T for their patience and their valuable advice during the seminars and courses. In addition, I thank to my classmates who contributed their comments during our meetings in the seminar classes. Furtheremore, I thank to Mitsubishi corporations for offering me a 3 years scholarship to support my studies at Kyushu University. Kyushu University itself has provided all of us in the university all necessary facilities to conduct successful academic researches.

\section{REFERENCES}

1. Al-Anani, Khalil. 2007. The Muslim Brotherhood in Egypt: The Aging Wrestles the Time. Al- Shuruk International Press, Cairo, Egypt.

2. Eland,Evan.2013. The United States Should Quit Meddling in Egypt. Antiwar.com 2014. U.S.A: http://original.antiwar.com/eland/2013/07/16/the-united-states-should-quit-meddling-in-egypt Harry Elmer Barnes. 1924. Sociology and Political Theory. W. F. Etherington \& co., New York, Alfered A. Knope,Inc http://original.antiwar.com/eland/2013/07/16/the-united-states-should-quit-meddling-in-egypt/

3. Huntington, Samuel P. 1996. The Clash of Civilizations and the Remaking of World Order.

4. Maszner, Beata. Przylska. 2011. Arab Spring. U.S.A.

5. Muhammad, Al Baz. 2010. Memoir of the Preaching and Preacher. Kunuz Publication, Cairo.

6. Munson, Ziad.2001. ISLAMIC MOBILIZATION: Social Movement Theory and the Egyptian Muslim Brotherhood. The Sociological Quarterly, Volume 42, Number 4, pages 487-510. University of California Press. U.S.A.

7. Said, Edward. 1997. Covering Islam. Ed. Revue. New York: Vintage.

8. Sicker, Martin. 2000. The Islamic World in Ascendancy from the Arab Conquests to the Siege of Vienna. Praeger Westport, Connecticut. London:

http://books.google.co.jp/books?id=xIWsMcwZ9vEC\&lpg=PA5\&ots=rJeCdeCGfg\&dq=Martin\%20Sicker\%202000 \&lr\&pg=PA26\#v=onepage\&q=Martin\%20Sicker\%202000\&f=false

9. Pargeter, Alison. 2010. The Muslim Brotherhood: the Burden of Tradition. India: Thomson Press.

10. Richard P, Mitchell. 1969. The Society of the Muslim Brothers. Oxford University Press, Inc. New York, New York 10016-4314. Islamic Egypt. 2011. EgyptGiftshop.com 2011. Mohamed Rashad Web design services. Goods and services provided by Egypt gift shop (Egypt) Sold by 2CheckOut.com Inc. (Ohio, USA)

11. Ramadan, Tariq. 2011. L'Islam et le Reveil Arabe. Lyon: Presses du Chatelet

12. Ramadan, Tariq. 2004. Western Muslims and the Future of Islam. New York: Oxford. University Press.

13. Pipes, Daniel. 2003. Militant Islam Reaches America. New York: W.W. Norton \& Company. The Meir Amit Intelligence and Terrorism Information Center. 2011. The Muslim Brotherhood's Education, Preaching and Socialactivity. CRETHIPLETHI.com. Netherlands. 


\section{Author's biography with Photo}

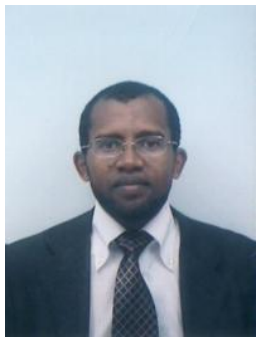

A Multilingual of Arabic, English, French, Shikomori, and Japanese, Mohamed Chami MKOUBOI holds B.A. in Business Administration from Ritsumeikan Asia Pacific University (APU), a Master Degree in Comparative Studies of Politics and Administration in Asia at Kyushu University. He is currently writing his PhD dissertation in the Recruiting Strategies of the Egyptian Muslim Brotherhood' at Kyushu University, Japan.

Potential subjects are Islamic Studies, International Politics, International Relations and Political Science.

Potential Regions for his studies are East Asia, the Middle Eastern and the North African Regions. 